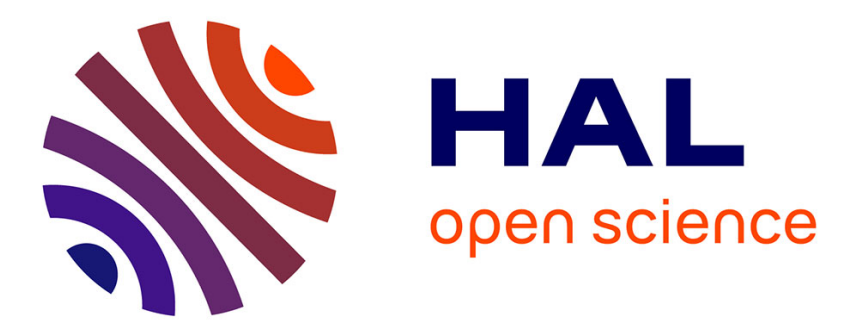

\title{
The immunoglobulin-like superfamily member IGSF3 is a developmentally regulated protein that controls neuronal morphogenesis.
}

\author{
Alessia Usardi, Keerthana Iyer, Séverine M Sigoillot, Antoine Dusonchet, \\ Fekrije Selimi
}

\section{To cite this version:}

Alessia Usardi, Keerthana Iyer, Séverine M Sigoillot, Antoine Dusonchet, Fekrije Selimi. The immunoglobulin-like superfamily member IGSF3 is a developmentally regulated protein that controls neuronal morphogenesis.: IGSF3 and granule cell development. Developmental Neurobiology, 2016, 10.1002/dneu.22412 . inserm-01343251

\section{HAL Id: inserm-01343251 https://www.hal.inserm.fr/inserm-01343251}

Submitted on 7 Jul 2016

HAL is a multi-disciplinary open access archive for the deposit and dissemination of scientific research documents, whether they are published or not. The documents may come from teaching and research institutions in France or abroad, or from public or private research centers.
L'archive ouverte pluridisciplinaire HAL, est destinée au dépôt et à la diffusion de documents scientifiques de niveau recherche, publiés ou non, émanant des établissements d'enseignement et de recherche français ou étrangers, des laboratoires publics ou privés. 
Title: The immunoglobulin-like superfamily member IGSF3 is a developmentally regulated protein that controls neuronal morphogenesis

Running title: IGSF3 and granule cell development

Alessia USARDI ${ }^{1}$, Keerthana IYER ${ }^{1}$, Séverine M. SIGOILLOT ${ }^{1}$, Antoine DUSONCHET ${ }^{1}$, Fekrije SELIMI ${ }^{1 *}$

${ }^{1}$ Center for Interdisciplinary Research in Biology, Collège de France, CNRS, INSERM, PSL Research University, Paris, France

*Corresponding author: Fekrije Selimi, fekrije.selimi@college-de-france.fr, tel.: +331442716 54, fax: $+\underline{+33144271691}$

Acknowledgements:

We would like to thank M. Albert for technical assistance, Dr. C. Racca (Newcastle Univ., UK) for helpful discussions; Pr M. E. Hatten (Rockefeller Univ., USA) for the anti-TAG1 antibody, Dr Passafaro (Univ. of Milan, Italy) for the anti-TSPAN7 antibody; Dr. A. Koulakoff (CIRB, France) for the hGFAP-GFP mice; J. Teillon, N. Quenech'du, and P. Mailly from the CIRB Imaging Facility; and J.-C. Graziano from the CIRB Animal Facility. This work has received support under the program « Investissements d'Avenir » launched by the French Government and implemented by the ANR, with the references: ANR-10-LABX-54 MEMO LIFE. Funding was also provided by Fondation Bettencourt Schuller, Ecole des Neurosciences de Paris, Emergence UPMC, Association Française du Syndrôme de Rett, ATIP-AVENIR, FENS Boehringer Ingelheim award and Fondation pour la Recherche Médicale. 


\begin{abstract}
The establishment of a functional brain depends on the fine regulation and coordination of many processes, including neurogenesis, differentiation, dendritogenesis, axonogenesis, and synaptogenesis. Proteins of the immunoglobulin-like superfamily (IGSF) are major regulators during this sequence of events. Different members of this class of proteins play nonoverlapping functions at specific developmental time-points, as shown in particular by studies of the cerebellum. We have identified a member of the little studied EWI subfamily of IGSF, the protein IGSF3, as a membrane protein expressed in a neuron specific- and time dependent-manner during brain development. In the cerebellum, it is transiently found in membranes of differentiating granule cells, and is particularly concentrated at axon terminals. There it co-localizes with other IGSF proteins with well-known functions in cerebellar development: TAG-1 and L1. Functional analysis shows that IGSF3 controls the differentiation of granule cells, more precisely axonal growth and branching. Biochemical experiments demonstrate that, in the developing brain, IGSF3 is in a complex with the tetraspanin TSPAN7, a membrane protein mutated in several forms of Xlinked intellectual disabilities. In cerebellar granule cells, TSPAN7 promotes axonal branching and the size of TSPAN7 clusters is increased by downregulation of IGSF3. Thus IGSF3 is a novel regulator of neuronal morphogenesis that might function through interactions with multiple partners including the tetraspanin TSPAN7. This developmentally
\end{abstract}


regulated protein might thus be at the center of a new signaling pathway controlling brain development.

Five keywords: development, cerebellum, cell adhesion molecules, Ig domains, neuronal morphogenesis 


\section{INTRODUCTION}

Many steps of brain development involve cell-cell interactions, including neuronal migration, elongation of dendritic and axonal protrusions as well as formation and maintenance of synapses. The complexity and precise coordination of all these events has been illustrated in detail in the developing cerebellar cortex, in particular by the study of granule cells. Granule cell precursors (GCPs) migrate tangentially from the rhombic lip to the surface of the cerebellar primordium where they form the external granular layer (EGL) and go through a second period of proliferation (Sotelo, 2004; ;Alder et al., 1996; Hatten and Heintz, 1995). Their differentiation begins in the inner EGL, where they extend their axons, the parallel fibers, before starting their radial migration along the Bergman glia, which serve as a scaffold. When they reach the internal granular layer, below the Purkinje cells, granule cells terminate their differentiation and are contacted by their inputs, the mossy fibers (Sotelo, 2004). Their axons, the parallel fibers, form synapses with their targets in the molecular layer, the Purkinje cells and the interneurons.

All these steps need to be finely orchestrated during development. The family of cell adhesion molecules (CAMs), which includes cadherins, Ig superfamily (IGSF) proteins and integrins, plays a crucial role in this process (Shapiro et al., 2007; Maness and Schachner, 2007). IGSFs are characterized by at least one immunoglobulin (lg) domain, and generally contain a transmembrane and a short intracellular domain. Many, like NCAM, L1 or DSCAM proteins, also 
contain Fibronectin type III domains (Shapiro et al. 2007). Perturbations of the function of IGSF proteins lead to defects in neuronal migration and axonal growth. For example, the phenotype of L1-CAM knockout mice is characterized by pathfinding errors of corticospinal, retino-collicular, thalamocortical and callosal axons, as well as dendritic misorientation of cortical pyramidal neurons and abnormal positioning of dopaminergic neurons (Cohen et al., 1998; Dahme et al., 1997; Maness and Schachner, 2007).

Four EWI proteins form a little studied subfamily of IGSF proteins: EWI2/IGSF8/PGRL, EWI-F/Ptgfrn/CD9P-1, EWI-101/IGSF2 and EWI-3/IGSF3. They all share a Glu-Trp-Ile (EWI) motif in their extracellular region, are strongly similar to each other (23-35\% aminoacid similarity), and differ by the number of C2-type IgG domains that they contain (Charrin et al., 2001; Clark et al., 2001; Ruegg et al., 1995; Stipp et al., 2001). IGSF8, Ptgfrn and IGSF2 have been involved in diverse cellular processes requiring cell-cell interaction such as oocyte fertilization (Ellerman et al., 2003), viral infection (Bhella, 2015; Gordón-Alonso et al., 2012; Montpellier et al., 2011), T cell proliferation, and formation and maintenance of the immune synapse (Rivas et al., 1995). IgSF3 is expressed in several organs including the brain (Saupe et al., 1998) and IgSF8 is expressed in the growing axons of olfactory sensory neurons (Ray and Treloar, 2012). Despite their expression in the brain, the function of EWI proteins in this organ remains elusive.

Here, we show that IGSF3 is expressed in various brain regions in a developmentally regulated manner. In the cerebellum, IGSF3 is expressed in 
granule cells during their differentiation and controls their morphogenesis. We also present evidence that IGSF3 forms a complex with the tetraspanin TSPAN7 in the developing brain, that TSPAN7 controls axonal branching and that IGSF3 restricts the size of TSPAN7 clusters in cultured cerebellar granule cells. Thus IGSF3 is a new modulator of neuronal morphogenesis that could play this role partially through interaction with the tetraspanin TSPAN7. 


\section{METHODS}

All animal protocols and animal facilities were approved by the Comité Régional d'Ethique en Expérimentation Animale (no. 00057.01) and the veterinary services (C75 05 12).

\section{Quantitative RT-PCR}

RNA samples were obtained from mouse cerebella at different ages or mixed cerebellar cultures using the RNeasy Mini kit (Qiagen). cDNA were amplified using the SuperScript ${ }^{\circ}$ VILO ${ }^{T M}$ cDNA Synthesis kit (Life technologies) according to manufacturer's instructions. Quantitative PCR was performed using the Light Cycler 480 SYBR Green I Master Mix (Roche Applied Science) and the following primers: Igsf3 Fwd 5'-aagtacagatcgttagcacggt-3' and Rev 5'-ggtgtgacattcatactcgcc-3', Igsf8 Fwd 5'-ggactctggcttttatgagtgc-3' and Rev 5'-ggaggggcagcagatacc-3', Igsf2 Fwd 5'-agcccttggaactcacctgt-3' and Rev 5'-catcaccggccacaaacct-3', Ptgfrn Fwd 5'-gaccaaggccactacaagtgt-3' and Rev 5'-gacgtggtagacgcgatacat-3', Tspan7 Fwd 5'-atggcatcgaggagaatggag-3' and Rev 5'-tgagcacatagggagcatttg-3', Gapdh Fwd 5'-cctgcgacttcaacagcaact3' and Rev 5'-ggtccagggtttcttactccttg-3', Rp/13 Fwd 5'cactctggaggagaaacggaagg-3' and Rev 5'-gcaggcatgaggcaaacagtc-3'.

\section{cDNA constructs}

The following plasmids were used: pCAG (Matsuda and Cepko, 2004), pCAG-mbGFP: membrane GFP cDNA was subcloned into the pCAG vector, pCAG-Igsf3: mouse Igsf3 cDNA (Accession number: BC052892) obtained 
from the pSPORT1-Igsf3 vector (Dharmacon) was subcloned into the pCAG vector, pBI-GFP: a gift from Bert Vogelstein (Addgene plasmid \# 16623), pBIGFP-Igsf3 (mouse lgsf3 cDNA was subcloned into the pBI-GFP vector), pIRES2eGFP-Tspan7 (Bassani et al., 2012).

\section{Neuronal cultures and gene expression modification}

We prepared dissociated cultures of mouse cerebellar neurons using a modified version of a previously described protocol (Tabata et al., 2000). Briefly, neurons were dissociated from P0 cerebella obtained from Swiss mice, in the case of mixed cerebellar cultures, or P6 cerebella for granule cell cultures. Ninety microliters of the cell suspension $\left(5 \times 10^{6}\right.$ cells $/ \mathrm{mL}$ for mixed cerebellar cultures and $2.5 \times 10^{6}$ cells $/ \mathrm{mL}$ for granule cell cultures) were plated onto the centre of poly L-ornithine $(0.5 \mathrm{mg} / \mathrm{mL})$ coated glass coverslips. Cells were maintained in medium supplemented with bovine serum albumin (100 $\mu \mathrm{g} / \mathrm{mL})$ and a glial proliferation inhibitor, cytosine arabinoside $(4 \mu \mathrm{M})$.

For loss of function experiments, granule cells were treated at DIV0 with either $0.5 \mu \mathrm{M}$ Accell Non-Targeting siRNA as control (Thermo Fisher Scientific) or $0.5 \mu \mathrm{M}$ Mouse silgsf3 siRNA following manufacturer's instructions (Thermo Fisher Scientific). For gain of function experiments, granule cells were transfected at DIV1 using Lipofectamine 2000 (Life Technologies) according to the manufacturer's protocol. After 96 hours granule cells were fixed for immunocytochemistry or lysed for mRNA extraction. 


\section{Transfection of HEK293 cells}

HEK293 cells were maintained in DMEM-glutamax $4.5 \mathrm{~g} / \mathrm{L}$ glucose plus pyruvate (Life Technologies) supplemented with 10\% fetal bovine serum and $100 \mathrm{U} / \mathrm{mL}$ penicillin/ $100 \mu \mathrm{g} / \mathrm{mL}$ streptomycin, at $37 \mathrm{C}$ in a $5 \% \mathrm{CO} 2$ atmosphere. Cells were transfected 24 hours after plating using Lipofectamine 2000 (Life Technologies). After 48 hours, cells were fixed for immunocytochemistry or lysed for protein extraction.

\section{In situ hybridization}

In situ hybridization was performed using a previously described protocol with few modifications (Bally-Cuif et al., 1992). Briefly, $100 \mu \mathrm{m}$ thick-floating vibratome sections were obtained from paraformaldehyde fixed mouse brains at postnatal day 0 (P0), P7 and P21. The probe sequence for lgsf3 corresponded to $1608-2479$ bp for mouse cDNA NM_207205.1. The riboprobe was used at a final concentration of $2 \mu \mathrm{g} / \mu \mathrm{L}$. Duration of the proteinase $\mathrm{K}(10 \mu \mathrm{g} / \mathrm{mL})$ treatment was 30 seconds for $\mathrm{P} 0$ and $\mathrm{P} 7$ brain sections, and 10 minutes for P21 brain sections. The anti-digoxigenin conjugated to alkaline phosphatase antibody (Biocompare, Roche) was used at a dilution of $1 / 2000$.

\section{Immunohistochemistry}

Swiss mice (Janvier, France) or hGFAP-GFP mice were perfused with $4 \%$ paraformaldehyde in PBS, pH 7.4. Brains were postfixed for one hour (for adult mice) or overnight (for P0 and P7) with $4 \%$ PFA in PBS at $4^{\circ} \mathrm{C}$, then 
cryoprotected in $30 \%$ sucrose/PBS for two nights. $30 \mu$ m-thick sections were obtained using a freezing microtome.

Blocking of non-specific binding sites was performed using $4 \%$ Donkey serum/PBS. Primary antibodies were diluted in $1 \%$ Donkey serum $/ 1 \%$ Triton X-100/PBS and incubated at $4^{\circ} \mathrm{C}$ overnight. Donkey Alexa Fluor® 488, 594 and 647 conjugated secondary antibodies (Thermo Fisher Scientific) were diluted in $1 \%$ Donkey serum/1\% Triton X-100/PBS. Washes were performed with $1 \%$ Triton $\mathrm{X}-100 / \mathrm{PBS}$.

\section{Immunocytochemistry}

Cells were fixed with cold 4\% PFA in PBS for $15 \mathrm{~min}$ at room temperature, rinsed with PBS and incubated with 4\% Donkey serum $/ 0.2 \%$ Triton X100/PBS. Primary and secondary antibodies were diluted in $0.2 \%$ Triton $X$ 100/PBS. Nuclear Hoechst counterstaining was performed for $15 \mathrm{~min}$ at room temperature.

Primary antibodies

Sheep anti-IGSF3 (1:750 for brain sections, 1:400 for fixed cells, R\&D Systems), rabbit anti-IGSF3 (for Western blotting, 1:1000, Sigma), mouse anti-Calbindin (1:5000, Swant), guinea pig anti-GLAST (1:7000, Chemicon), anti-PAX6 (Covance, 1:300), anti-NCAM L1 (1:500, Millipore), guinea pig antiVglut1 (1:5000, Millipore), anti-TSPAN7 (1:500, a kind gift of Dr. Passafaro), anti-TAG1 (1:2, kindly provided by $\operatorname{Pr}$. Hatten), mouse anti- $\beta$ actin (1:50000, Abcam). 


\section{Immunoprecipitation}

P8 cerebella were homogenized in cold lysis buffer $(50 \mathrm{mM}$ Tris- $\mathrm{HCl} \mathrm{pH} 7.5,2$ mM EDTA, $150 \mathrm{mM} \mathrm{NaCl}, 1 \%$ Triton X-100, protease inhibitor cocktail (Sigma). Protein crosslinking was performed using $2 \mathrm{mM}$ dithiobis succinimidylpropionate (DSP) (ThermoFisher) for $30 \mathrm{~min}$ at room temperature, and stopped by adding $20 \mathrm{mM}$ Tris- $\mathrm{HCl} \mathrm{pH}$ 7.5. Immunoprecipitation was performed by incubating with Dynabeads (Invitrogen) pre-coated with either $10 \mu \mathrm{g}$ of goat/sheep lgG (Sigma) or $10 \mu \mathrm{g}$ of anti-IGSF3 (R\&D system) for 60 min at $4^{\circ} \mathrm{C}$ with constant rocking. After several washes with lysis buffer, immune complexes were eluted by resuspending the beads in sample buffer (6 M Urea, $2 \%(\mathrm{v} / \mathrm{v})$ SDS, $200 \mu \mathrm{L}$ of $20 \mathrm{mg} / \mathrm{mL}$ Bromophenol blue, $62.5 \mathrm{mM}$ Tris- $\mathrm{HCl}, 10 \%(\mathrm{v} / \mathrm{v}) \quad \beta$-mercaptoethanol, $20 \%(\mathrm{v} / \mathrm{v})$ glycerol) and heating the samples at $65^{\circ} \mathrm{C}$ for 15 min. Protein samples were resolved on a NuPAGE Novex $4-12 \%$ Bis-Tris gel (Invitrogen).

\section{Protein extraction and immunoblotting}

HEK-293H cells (Gibco) were plated at a density of $5 \times 10^{5} /$ well on coverslips previously coated with $10 \mu \mathrm{g} / \mathrm{mL}$ poly-D-lysine (Sigma). The day after plating cells were transfected with constructs of interest using Lipofectamine 2000 (Invitrogen). Cells were harvested in lysis buffer (50 mM Tris-HCl pH 7.5, 150 $\mathrm{mM} \mathrm{NaCl}, 1 \%(\mathrm{v} / \mathrm{v})$ SDS, $0.2 \%(\mathrm{v} / \mathrm{v})$ sodium azide, $5 \%(\mathrm{w} / \mathrm{v})$ sodium deoxycholate, $0.1 \%(\mathrm{v} / \mathrm{v}) \mathrm{NP}-40)$, sonicated for 5 seconds three times and incubated at $4^{\circ} \mathrm{C}$ for $30 \mathrm{~min}$. Lysates were then centrifuged at $20,000 \mathrm{~g}$ for 30 min and supernatants were collected for protein dosage using the Pierce BCA Protein Assay kit (Thermo Fisher Scientific). $10 \mu \mathrm{g}$ of proteins were resolved 
on a NuPAGE Novex $4-12 \%$ Bis-Tris gel (Invitrogen). Immunoblotting was performed in $0.2 \%$ Tween/PBS, and signals were revealed using Amersham ECL Prime Western Blotting Detection Reagent (GE Healthcare) or SuperSignal West Femto Chemiluminescent Substrate (Thermo Fisher).

\section{Microscopy and data analysis}

Images for analysis of the morphology of granule cells were acquired on a Leica SP5 confocal microscope at 40X magnification using a $0.5 \mu \mathrm{m}$ z-step (figure 5), or on the spinning disk confocal microscope at 25X magnification using a $0.3 \mu \mathrm{m}$ z-step size (figure 6). Acquired images were stitched together using the Grid/Collection Stitching plugin of ImageJ (Preibisch et al., 2009). Dendrites and axons were traced on a maximal stack projection for each stack using the NeuronJ plugin of ImageJ. The main axon, defined as the thinnest and longest neurite coming out of the granule cell soma, was first traced, followed by collaterals starting from this main axon. Dendritic branches were traced and measured to provide total dendritic length, mean number of dendritic branches and mean dendrite size per neuron.

Images for quantification of granule cell/Purkinje cell synapses (VGLUT1/CABP positive puncta) in mixed cultures were acquired on the confocal microscope at $63 \mathrm{X}$ magnification using a $0.2 \mu \mathrm{m}$ z-step. Synaptic contacts were analyzed using an ImageJ-customized macro. The CaBP and the VGLUT1 objects found above a user-defined threshold were selected. Image calculator was used to extract the signal common to the CaBP and VGLUT1 images: the number and volume of these puncta were quantified with the 3D Object counter plugin from ImageJ. 
Images for quantification of Tspan7 puncta were acquired on the confocal microscope at 63X magnification zoom 4. Tspan7 puncta were analyzed using the image J tool "analyze particles" after background substraction (rolling ball radius, 50 pixels) and selection of a user-defined threshold. Puncta with a size between 0.01 and $0.8 \mu \mathrm{m}^{2}$ were included in the quantification.

The level of IGSF3 knockdown was assessed on images taken at 20X magnification with the confocal microscope. Fluorescence intensity was measured as integrated density using ImageJ after backgroung substraction (rolling ball radius, 50 pixels).

\section{Statistical analysis}

Statistical analysis was conducted using the GraphPad Prism software. After checking normality of distribution and equality of variance, unpaired T-test was used to compare two samples, or two-way ANOVA to perform comparisons in experiments with two changing parameters (figure 5B). The Kolmogorov-Smirnov test was used to compare the frequency distributions of TSPAN7 cluster size in figure 7. 


\section{RESULTS}

IGSF3, a new IGSF-CAM developmentally regulated in the brain

Expression of Igsf8 and Igsf3 mRNAs in the human brain and the role of EWI proteins in regulating cell-cell interactions in diverse systems (Zhang et al., 2003; Stipp et al., 2003; Ellerman et al., 2003; Kolesnikova et al., 2009; Gordón-Alonso et al., 2012) suggest a role during normal brain development. Accordingly, both Igsf3 and Igsf8 mRNAs are expressed at high levels and dynamically in the mouse cerebellum during the first three postnatal weeks, a critical period for the development of this structure, while Ptgfrn and Igsf2 are expressed at low levels or absent, respectively (Figure 1A). In situ hybridization (ISH) experiments for Igsf3, the most abundant member of the family in the developing cerebellum, confirmed this strikingly dynamic expression. Igsf3 mRNA was detected at high levels at $\mathrm{P} 0$, at the beginning of the intense period of granule cells proliferation, and P7, a stage of intense cellular migration and differentiation, while it was undetectable in the adult cerebellum. These ISH analyses also showed high and dynamically regulated levels of Igsf3 mRNA in various other brain regions during the first postnatal weeks, such as the olfactory bulb, cortex, hippocampus, superior colliculus, inferior olive and spinal cord (Figure 1B). Immunofluorescent labeling showed the correlation of the expression pattern of the IGSF3 protein with the one found for the mRNA using in situ hybridization (Figure 1C). The specificity of the polyclonal antibody recognizing IGSF3 was demonstrated using transfection of HEK293 cells (Figure sup. 1) and knockdown experiments in 
cerebellar granule cells (Figure sup. 2C). In the cerebral cortex, the IGSF3 protein is found in the most superficial layer at $\mathrm{PO}$ and becomes restricted to layer $2 / 3$ with maturation. In the hippocampus, IGSF3, initially seen in all subfields, becomes restricted to the dentate gyrus. In the olfactory bulb, IGSF3 localizes to both mitral cells and granule cell layers.

Thus IGSF3 is expressed in a developmentally regulated pattern in various brain regions. This is reminiscent of the pattern observed for other molecules belonging to the IGSF-CAMs family such as F3, TAG-1 and L1-CAM (Kuhar et al., 1993; Stottmann and Rivas, 1998; Powell et al., 1997; Sakurai et al., 2001)

IGSF3 is a marker of differentiating cerebellar granule cells and parallel fibers

The various functions played by IGSF-CAMs depend on the tight spatiotemporal control of their cellular and subcellular localization during development. In the cerebellum, for example, F3/contactin undergoes sharp changes in its cellular distribution, concomitant with neuronal differentiation (Bizzoca et al., 2003, 2009). To gain further insight into the role of IgSF3 during brain development, we performed a detailed analysis of its cellular and subcellular localization in the mouse cerebellum at P0 and P7.

In situ hybridization experiments showed that Igsf3 mRNA strongly localizes to the developing internal granular layer (IGL) (Figure 2A), whereas the IGSF3 protein is found both in the IGL and the nascent molecular layer (Figures $2 B$ and $2 \mathrm{C}$ ). This pattern is consistent with an expression of IGSF3 by post- 
mitotic granule cells, which extend their axons in the molecular layer and are the major cell type in the IGL. PAX6 is a transcription factor expressed in both mature granule cells and their precursors in the external granular layer (EGL) (Engelkamp et al., 1999; Yamasaki et al., 2001). Co-immunostaining experiments showed that nuclei from IGSF3 expressing cells were positive for PAX6 both in mouse brain sections (Figure 3A), and in dissociated cerebellar cultures at DIV0, a timepoint when cells can be clearly isolated (Figure 3B), thus confirming expression of IGSF3 by granule cells.

Purkinje cells extend their dendrites in the molecular layer and could thus be another source of IGSF3 in the cerebellum. Co-immunolabeling with an antibody against Calbindin (CaBP), a cytoplasmic marker specifically labeling PCs (Takahashi-Iwanaga et al., 1986), revealed IGSF3 around Purkinje cell dendrites (Figure 2C), but ISH experiments did not show any evident expression of Igsf3 mRNA in Purkinje cells (Figure 2A). These results suggest that Purkinje cells do not express IGSF3 and that its presence in the developing molecular layer is most likely due to its localization in parallel fibers.

The intense staining for IGSF3 detected at P0, a time when only few granule cells and parallel fibers are present, suggested that glia might be another source of IGSF3 expression in the developing brain. Indeed, the developing molecular layer also contains fibers from Bergmann glia that provide a scaffold for granule cell radial migration towards the IGL. Immunolabeling for IGSF3 using sections from a reporter mouse line with fluorescently labeled astrocytes and radial glial cells (Nolte et al., 2001) revealed some localization 
of IGSF3 immunostaining in fibers corresponding to Bergman glia in the P7 molecular layer (Figure $3 \mathrm{C}$ and D). Moreover, some isolated glial cells, identified in cerebellar cultures at DIVO using immunolabeling for the glutamate aspartate transporter (GLAST) (Schmitt et al., 1997), clearly expressed IGSF3 (arrows in Figure 3E). Taken together, these results show that differentiating granule cells are the major source of IGSF3 in the developing cerebellum, while glia could also express this marker at early stages of development.

The successive stages of granule cell differentiation are characterized by the expression of different combinations of cell adhesion molecules, in particular of the IGSF-CAM family, with specific subcellular localization. TAG-1 is transiently expressed in pre-migratory granule cells in the inner part of the external granular layer (iEGL) starting from the time of parallel fiber extension (Yamamoto et al., 1986; Baeriswyl and Stoeckli, 2008; Kuhar et al., 1993), and disappears from granule cell axons when they connect Purkinje cell dendrites (Stottmann and Rivas, 1998). L1-CAM is expressed by more differentiated granule cells, and localizes in fasciculating parallel fibers (Persohn and Schachner, 1987). IGSF3 could likewise characterize a specific stage of granule cell differentiation. Extensive colocalization between IGSF3 and both TAG1 in the iEGL (Figure 4A and B), and L1 in the molecular layer (Fig. 4C and D) was shown by co-immunolabeling experiments in P7 cerebellar sections. IGSF3 was also detected, albeit at lower levels, all around granule cell somata and ascending axons in the internal granular layer. The 
high levels of IGSF3 found in granule cell axonal terminals around Purkinje cell dendrites suggested it might be present at the parallel fiber/Purkinje cell (PF/PC) synapses. However, colocalization experiments showed only limited colocalization of IGSF3 with VGluT1, a marker of mature PF/PC synapes (Miyazaki et al., 2003)(Figure 4E and F), suggesting that IGSF3 disappears when PF/PC synapses starts to mature.

Taken together, these results show that IGSF3 in the cerebellum is a marker of developing, but not mature, granule cells, both at the pre- and postmigratory stages. These findings raise several possibilities as to the developmental processes in which IGSF3 could be implicated during cerebellar development.

IGSF3 regulates cerebellar granule cell differentiation

IGSF-CAMs have been implicated in several processes controlling cerebellar development, including proliferation, differentiation, migration and synaptogenesis (Buttiglione et al., 1996, 1998; Xenaki et al., 2011; Baeriswyl and Stoeckli, 2008; Burden-Gulley and Lemmon, 1995; Hortsch and Umemori, 2009; Maness and Schachner, 2007; Schäfer and Frotscher, 2012; Stoeckli, 2004; Walsh and Doherty, 1997; Washbourne et al., 2004; Wiencken-Barger et al., 2004; Yoshihara et al., 1991). Given the expression pattern of IGSF3 in the cerebellum, it could be involved in any of these processes. To gain further insights, functional experiment using knockdown or overexpression 
approaches were performed in cerebellar cultures. First, we developed an RNA interference approach to suppress IGSF3 expression using small interfering RNAs (siRNA). In mixed cerebellar cultures, the expression pattern of Igsf3 mirrors the one found in vivo, since its mRNA levels are highest during the first few days with a peak at DIV4 (Figure 5A and sup. 2A), and they are higher than the levels of of Igsf8 mRNA. A mixture of four different siRNAs targeting Igsf3 (silgsf3) applied at DIV0 induced more than $80 \%$ down-regulation of Igsf3 mRNA by DIV4 when compared to control nontargeting siRNAs (siCTR) as assessed by qRT-PCR (Figure sup. 2B), and greatly reduced the signal obtained by IGSF3 immunolabeling (Figure sup. 2C). No significant effect on the mRNA levels of Igsf8 and Bai3, two other genes expressed in cerebellar mixed cultures, could be detected in these conditions, further showing the specificity of our approach.

To test whether IGSF3 is important for their survival and proliferation, we performed knockdown of IGSF3 in cerebellar granule cell cultures right after seeding. In both Igsf3 and control siRNAs treated cultures, the total cell density remained stable between DIV1 and DIV4, with only a small, but not significant, decrease between DIV2 and DIV4 after IGSF3 knockdown (Figure $5 B$, left graph). The proportion of proliferating cells in granule cell cultures, as assessed by Ki67 labeling, was not changed by silgsf3 treatment compared to siCTR at the different stages (Figure 5B, right graph). Thus IGSF3 does not control the proliferation and survival of granule cells.

IGSF3 could play a role in GC differentiation. To test this hypothesis, we quantified dendritic and axonal morphology in isolated GFP labeled granule 
cells following knockdown or overexpression of IGSF3. A $65 \%$ increase in total axonal length was shown in granule cells treated with silGSF3 when compared to control cells (siCTR: $393.3 \pm 29.77 \mu \mathrm{m}$ and silGSF3: $651.8 \pm 80.09$ $\mu \mathrm{m}$. Unpaired T-test, $p<0.05$, Figure $5 \mathrm{C}$ ), while axon branching was not affected. The total dendritic length per neuron and the mean dendrite length were significantly decreased by IGSF3 knockdown when compared to controls (total length: siCTR: $588.4 \pm 94.2 \mu \mathrm{m}$ and silGSF3: $330.9 \pm 25.5 \mu \mathrm{m}$. Unpaired T-test, $p<0.01$; mean length: siCTR: $19.9 \pm 2.2 \mu \mathrm{m}$ and silGSF3: $13.22 \pm 1.13 \mu \mathrm{m}$. Unpaired T-test, $p<0.05$; Figure $5 \mathrm{C}$ ), while the number of dendritic processes was not changed. Conversely, IGSF3 overexpression in granule cells resulted in significantly shorter axons (CTR: 1096 $\pm 110.4 \mu \mathrm{m}$ and IGSF3: $769 \pm 61.54 \mu \mathrm{m}$, unpaired T-test, $\mathrm{p}<0.05$, Figure $5 \mathrm{D}$ ) and less axonal branches. Dendritic morphology was also affected with slightly less numerous but longer dendrites following IGSF3 overexpression leading to an increased total dendritic length per neuron (total length - CTR: $271.3 \pm 26.8 \mu \mathrm{m}$ and IGSF3: $451.6 \pm 55.2 \mu \mathrm{m}$, unpaired T-test, $\mathrm{p}<0.01$; mean length - CTR: $11.04 \pm 0.87 \mu \mathrm{m}$ and IGSF3: $23.57 \pm 1.43 \mu \mathrm{m}$, unpaired T-test, $p<0.0001$; Figure 5D). Altogether, these results show that IGSF3 controls granule cell differentiation by inhibiting the growth of their axons and altering their dendritic morphology. Through this inhibition of axonal growth, IGSF3 could control the timing of synapse formation. Quantification of the number and size of VGLUT1 puncta in cerebellar mixed cultures at DIV4 after IGSF3 knockdown did not reveal any changes compared to control conditions (Figure sup. 2D). Overall, our results show that a major role for IGSF3 is to control the 
morphological differentiation of cerebellar granule cells, before they make synaptic contacts with their targets. No role was identified in other processes that can be regulated by other IGSF-CAMs such as cell proliferation and survival, or synaptogenesis.

IGSF3 is in a complex with the tetraspanin TSPAN7 and negatively modulates the size of TSPAN7 clusters

L1-CAM promotes neurite outgrowth by either homophilic binding or heterophilic binding to other Ig-CAMs, such as NCAM (Grumet and Edelman, 1988; Lemmon et al., 1989). Given the well known role of L1-CAM during cerebellar development (Sakurai et al., 2001), we tested whether it could interact with IGSF3 by performing affinity-purification of IGSF3 from P8 cerebellar (Figure 6B, top panel) or forebrain homogenates (data not shown). In both cases, L1-CAM could not be detected in the IGSF3-containing molecular complexes.

EWI proteins can bind directly to tetraspanins (Sala-Valdés et al., 2006; Stipp et al., 2001), which are transmembrane proteins with diverse functions such as regulation of cell migration, fusion and signaling (Hemler, 2005). Tetraspanins thus could be interacting partners of IGSF3 and play a role during cerebellar development. Using database mining (Doyle et al., 2008; http://mouse.brain-map.org/ - 24/09/2015) and analysis of mRNA expression levels by qRT-PCR (Figure 6A), we found that tetraspanin 7 (TSPAN7) is highly expressed during cerebellar development starting at E17. A sharp increase in its expression was detected after P7, concomitant with granule cell 
differentiation. In situ hybridization data from the BGEM database showed that TSPAN7 was highly expressed by cerebellar granule cells during development (http://www.stjudebgem.org/, Figure 6A). In cultured hippocampal neurons, TSPAN7 overexpression increases the number of axonal and dendritic filopodia (Bassani et al., 2012). Accordingly, overexpression of TSPAN7 in cultured cerebellar granule cells significantly increases the number of axon collaterals (CTR: $7.33 \pm 1.17$; TSPAN7: 11.03 \pm 1.17 ; Unpaired T-test, $p<0.05$, Figure $6 \mathrm{~B}$ ). It does not change other parameters such as total axon length, and the size and number of dendritic branches (Figure 6B).

We hypothesized that TSPAN7 and IGSF3 could interact and regulate neuronal morphogenesis. Indeed, unlike L1-CAM, TSPAN7 was readily detected in IGSF3 affinity-purified samples from P8 cerebellar extracts showing that IGSF3 and TSPAN7 form a complex in the developing mouse cerebellum (Figure 7A). Furthermore, immunolabeling of HEK293H cells cotransfected with cDNAs coding for both IGSF3 and TSPAN7 showed the presence of IGSF3 in TSPAN7 domains at the plasma membrane (Figure 7B). Immunostaining of cultured cerebellar granule cells also detected partial colocalization of endogenous IGSF3 and TSPAN7, in particular in neurites (Figure 7C). Overall, our results show that IGSF3 forms a complex with TSPAN7 in heterologous and neuronal cells and in the developing mouse brain, while it does not stably interact with L1-CAM. 
The tetraspanin TSPAN7 forms clusters in developing cerebellar granule cells (Figure 7C). Its expression in the cerebellum increases when IGSF3's expression starts to decrease at P7 and overexpression of either TSPAN7 or IGSF3 has an opposite effect on axonal branching. To test whether IGSF3 could influence TSPAN7 localization and function, we performed knockdown of IGSF3 followed by TSPAN7 immunostaining in cultured cerebellar granule cells. High-resolution imaging and quantification of the TSPAN7 clusters show that at DIV4, the size of TSPAN7 clusters was significantly increased by IGSF3 knockdown while their number was unchanged (Figure 7D). Our results thus suggest that IGSF3 controls neuronal morphogenesis partly through its ability to negatively modulate the size of TSPAN7 clusters. 


\section{DISCUSSION}

The role of the EWI subfamily of IGSF-CAMs during brain development is still unknown. Our study shows that IGSF3, one of its four members, is expressed in various neuronal populations during the formation of neuronal circuits. In the cerebellum, it is transiently expressed in granule cells before their final maturation. It is highly concentrated in their axon terminals where it colocalizes with TAG-1 and L1, two other IgCAMs. Functional analysis shows that IGSF3 controls the differentiation of cultured cerebellar granule cells, in particular by inhibiting axonal growth. Moreover, IGSF3 and the tetraspanin TSPAN7 are part of the same molecular complex in the developing brain, TSPAN7 promotes axonal branching and IGSF3 negatively modulates the size of TSPAN7 clusters in neurons. These results suggest a new signaling pathway for the regulation of neuronal differentiation during brain development.

In the cerebellum, different IGSF-CAMs mark different stages of granule cell maturation (Stoeckli, 2010; Kuhar et al., 1993). In the early postnatal period, the external granular layer (EGL) contains granule cell precursors (GCPs), whose proliferation is sustained by homotypic interneuronal contacts and whose differentiation is induced by interactions with astrocytes (Gao et al., 1991). Postmitotic/premigratory granule cells express TAG-1, and sit in the inner part of the external granular layer (Pickford et al., 1989; Furley et al., 1990; Yamamoto et al., 1990; Kuhar et al., 1993; Stottmann and Rivas, 1998). After a period of tangential migration, their soma migrates radially along glial 
fibers towards the internal granular layer, while the axon grows to form the parallel fibers. At this stage they express L1, another IGSF-CAM that is highly concentrated in granule cells axonal terminals (Lindner et al., 1983; Xenaki et al., 2011). IGSF3 is found in both TAG-1 positive and L1 positive granule cells. It is particularly concentrated in the developing molecular layer where it completely overlaps with $L 1$, but is also found in the cell bodies of granule cells in the IGL. Therefore, IGSF3 is a new marker that defines postmitotic differentiating granule cells, and whose expression is downregulated once differentiation is completed. Recently, it was shown that the level of the IGSF8 protein in the axon terminals of olfactory sensory neurons is downregulated by sensory input during development and is upregulated by lesion-induced reinnervation of the olfactory bulb (Ray and Treloar, 2012). Similarly F3 and TAG-1 are also regulated upon lesion (Haenisch et al., 2005; Soares et al., 2005). IGSF3 expression is downregulated at the time of mossy fiber synaptogenesis on granule cells and in many other neuronal populations after circuit maturation, suggesting a regulation of IGSF3 expression by neuronal activity.

IGSF-CAMs regulate cell migration, axon growth, fasciculation and guidance, and synaptic plasticity (Kamiguchi and Lemmon, 2000; Schachner, 1997; Walsh and Doherty, 1997). They play important roles in cerebellar granule cells during development. They control the differentiation of granule cell precursors, with TAG-1 and F3 acting antagonistically to regulate the proliferation of GCPs (Xenaki et al. 2011). TAG-1 is required for granule cell 
axon pathfinding (Baeriswyl and Stoeckli, 2008; Buttiglione et al., 1998) and the use of TAG-1 interfering antibodies in cerebellar cultures and slices is enough to impair axon emergence (Wang et al., 2011). L1 promotes axon growth, GC migration and synapse plasticity (Lemmon et al., 1989; Lindner et al., 1983; Schäfer and Frotscher, 2012). Our results, obtained using both lossof-function and gain-of-function experiments, show that, while the protein IGSF3 does not regulate neuronal survival and proliferation, it is an additional player in the regulation of granule cell differentiation, in particular axon elongation. It remains to be determined whether IGSF3 shares other functions with L1 and TAG-1 in the development of the cerebellum. IGSF3 is found in glial cells in dissociated cerebellar cultures at early stages and some IgSF3 can be localized in Bergmann glia fibers. Moreover the time course of IgSF3 expression in the developing cerebellum is similar to the one of astrotactin-1, a transmembrane protein that regulates granule cell migration along radial glia, suggesting another possible role of IGSF3 (Wilson et al., 2010).

Proteins belonging to the IGSF-CAMs family play different functions depending on the neuronal population and their subcellular localization. Similarly, IGSF3 could play diverse and specific roles in the different cell types and regions where it is expressed during brain development, and in the adult brain. In particular, IGSF3 expression is very high in regions such as the olfactory bulb and the hippocampus in the adult, suggesting a potential role in the integration of adult born neurons into neuronal circuits. 
Competition between IgCAMs regulates neuronal differentiation. For example TAG-1 is able to antagonize inhibitory effects on granule cell proliferation and axonal growth induced by F3, another IgCAM (Buttiglione et al., 1998; Xenaki et al., 2011). Similarly to F3 and contrary to L1, IGSF3 inhibits axonal elongation suggesting a possible interplay between IGSF3 and TAG-1/L1 for the control of axonal elongation during development. L1 has been shown to bind to Ig-class recognition molecules including TAG-1, F3 and NCAM (Thelen et al., 2002). Our affinity purification experiments did not reveal an interaction of IgSF3 with L1 in postnatal cerebellar extracts, suggesting that IGSF3 signaling involves other molecular partners.

Tetraspanins are a large family of membrane proteins expressed in a broad range of cell types and tissues. Their main function is to spatially organize transmembrane protein partners into functional microdomains called tetraspanin-enriched microdomains (TEMs) (Hemler, 2005). IGSF8 can directly bind several tetraspanins (Charrin et al., 2003; Clark et al., 2001; Sala-Valdés et al., 2006; Stipp et al., 2001), and both IGSF8 and PTGFRN interact indirectly with the tetraspanin CD151 (Clark et al., 2001; Sala-Valdés et al., 2006). IGSF8 links TEMs and the actin cytoskeleton by forming a bridge between tetraspanins and ezrin-radixin-moesin proteins (Sala-Valdés et al., 2006). Regulation of the cytoskeleton dynamics, through the control of both actin and microtubule filaments, is necessary for axon growth and guidance (Schaefer et al., 2008; Dent and Gertler, 2003). Our results show that, in the developing brain and cerebellum, IGSF3 forms a molecular complex with the tetraspanin TSPAN7, which is highly expressed by cerebellar granule cells 
during development and in the adult cerebellum, and can regulate axon branching. IGSF8/EWI-2 binding to tetraspanins has been shown to prevent their interaction with TGF- $\beta$ receptors and thereby inhibit TGF- $\beta$ signaling (Wang et al., 2015). TSPAN7 modulates the morphology of dendritic cells and HIV transfer by modulating actin nucleation (Ménager and Littman, 2016). Thus these results altogether suggest that IGSF3 prevents TSPAN7's interaction with proteins inducing actin nucleation, thereby inhibiting modulation of axon morphogenesis by TSPAN7. TSPAN7 has been recently shown to be a key molecule for synapse maturation and function in hippocampal neurons. While down-regulation of IGSF3 expression at early stages of neuronal differentiation does not modify the ability of granule cells to form synaptic contacts with Purkinje cells, it remains to be determined whether IGSF3 regulates the final number of synapses.

Furthermore, IGSF3 might interact with various partners to regulate different neuronal parameters, such as axon versus dendrite morphogenesis. Interesting candidates are molecules of the extracellular matrix. For example, vitronectin binds to $\mathrm{CHL} 1$ and promotes neurite outgrowth in cerebellar granule cells (Katic et al., 2014). Vitronectin and IGSF3 have similar localization patterns in the developing cerebellum, suggesting that a possible interaction and interplay between these molecules for the regulation of neuronal morphogenesis during development.

This description of the developmental expression and functional role of IGSF3 during brain development opens new perspectives on the little studied EWI family of IGSF-CAMs. EWI proteins regulate a fundamental process, neuronal 
morphogenesis, and might have multiple functions as has been shown over the years for other IGSF-CAMS such as L1-CAM. The association of IGSF3 with TSPAN7 also points to the potential implication of EWI proteins in the etiology of neurodevelopmental disorders. Indeed, mutations affecting the gene coding for TSPAN7 are associated with cognitive defects in humans (Abidi et al., 2002; Zemni et al., 2000). An impaired TSPAN7-IGSF3 interaction following pathogenic mutations remains to be demonstrated and could lead to defects in brain development. 


\section{REFERENCES}

Abidi, F.E., Holinski-Feder, E., Rittinger, O., Kooy, F., Lubs, H.A., Stevenson, R.E., and Schwartz, C.E. (2002). A novel 2 bp deletion in the TM4SF2 gene is associated with MRX58. J. Med. Genet. 39, 430-433.

Alder, J., Cho, N.K., and Hatten, M.E. (1996). Embryonic precursor cells from the rhombic lip are specified to a cerebellar granule neuron identity. Neuron 17, 389-399.

Baeriswyl, T., and Stoeckli, E.T. (2008). Axonin-1/TAG-1 is required for pathfinding of granule cell axons in the developing cerebellum. Neural Develop. 3, 7.

Bassani, S., Cingolani, L.A., Valnegri, P., Folci, A., Zapata, J., Gianfelice, A., Sala, C., Goda, Y., and Passafaro, M. (2012). The X-linked intellectual disability protein TSPAN7 regulates excitatory synapse development and AMPAR trafficking. Neuron 73, 1143-1158.

Bhella, D. (2015). The role of cellular adhesion molecules in virus attachment and entry. Philos. Trans. R. Soc. Lond. B. Biol. Sci. 370, 20140035.

Bizzoca, A., Virgintino, D., Lorusso, L., Buttiglione, M., Yoshida, L., Polizzi, A., Tattoli, M., Cagiano, R., Rossi, F., Kozlov, S., et al. (2003). Transgenic mice expressing F3/contactin from the TAG-1 promoter exhibit developmentally regulated changes in the differentiation of cerebellar neurons. Dev. Camb. Engl. 130, 29-43.

Bizzoca, A., Corsi, P., and Gennarini, G. (2009). The mouse F3/contactin 
glycoprotein. Cell Adhes. Migr. 3, 53-63.

Burden-Gulley, S.M., and Lemmon, V. (1995). Ig superfamily adhesion molecules in the vertebrate nervous system: binding partners and signal transduction during axon growth. Semin. Dev. Biol. 6, 79-87.

Buttiglione, M., Revest, J.-M., Rougon, G., and Faivre-Sarrailh, C. (1996). F3 Neuronal Adhesion Molecule Controls Outgrowth and Fasciculation of Cerebellar Granule Cell Neurites: A Cell-Type-Specific Effect Mediated by the Ig-like Domains. Mol. Cell. Neurosci. 8, 53-69.

Buttiglione, M., Revest, J.M., Pavlou, O., Karagogeos, D., Furley, A., Rougon, G., and Faivre-Sarrailh, C. (1998). A functional interaction between the neuronal adhesion molecules TAG-1 and F3 modulates neurite outgrowth and fasciculation of cerebellar granule cells. J. Neurosci. Off. J. Soc. Neurosci. 18, 6853-6870.

Charrin, S., Le Naour, F., Oualid, M., Billard, M., Faure, G., Hanash, S.M., Boucheix, C., and Rubinstein, E. (2001). The major CD9 and CD81 molecular partner. Identification and characterization of the complexes. J. Biol. Chem. $276,14329-14337$.

Charrin, S., Le Naour, F., Labas, V., Billard, M., Le Caer, J.-P., Emile, J.-F., Petit, M.-A., Boucheix, C., and Rubinstein, E. (2003). EWI-2 is a new component of the tetraspanin web in hepatocytes and lymphoid cells. Biochem. J. 373, 409-421.

Clark, K.L., Zeng, Z., Langford, A.L., Bowen, S.M., and Todd, S.C. (2001). PGRL is a major CD81-associated protein on lymphocytes and distinguishes 
a new family of cell surface proteins. J. Immunol. Baltim. Md 1950 167, 51155121.

Cohen, N.R., Taylor, J.S., Scott, L.B., Guillery, R.W., Soriano, P., and Furley, A.J. (1998). Errors in corticospinal axon guidance in mice lacking the neural cell adhesion molecule L1. Curr. Biol. CB 8, 26-33.

Dahme, M., Bartsch, U., Martini, R., Anliker, B., Schachner, M., and Mantei, N. (1997). Disruption of the mouse L1 gene leads to malformations of the nervous system. Nat. Genet. 17, 346-349.

Dent, E.W., and Gertler, F.B. (2003). Cytoskeletal Dynamics and Transport in Growth Cone Motility and Axon Guidance. Neuron 40, 209-227.

Doyle, J.P., Dougherty, J.D., Heiman, M., Schmidt, E.F., Stevens, T.R., Ma, G., Bupp, S., Shrestha, P., Shah, R.D., Doughty, M.L., et al. (2008). Application of a translational profiling approach for the comparative analysis of CNS cell types. Cell 135, 749-762.

Ellerman, D.A., Ha, C., Primakoff, P., Myles, D.G., and Dveksler, G.S. (2003). Direct binding of the ligand PSG17 to CD9 requires a CD9 site essential for sperm-egg fusion. Mol. Biol. Cell 14, 5098-5103.

Engelkamp, D., Rashbass, P., Seawright, A., and van Heyningen, V. (1999). Role of Pax6 in development of the cerebellar system. Dev. Camb. Engl. 126, 3585-3596.

Furley, A.J., Morton, S.B., Manalo, D., Karagogeos, D., Dodd, J., and Jessell, T.M. (1990). The axonal glycoprotein TAG-1 is an immunoglobulin superfamily member with neurite outgrowth-promoting activity. Cell 61, 157- 
170.

Gao, W.O., Heintz, N., and Hatten, M.E. (1991). Cerebellar granule cell neurogenesis is regulated by cell-cell interactions in vitro. Neuron 6, 705-715.

Gordón-Alonso, M., Sala-Valdés, M., Rocha-Perugini, V., Pérez-Hernández, D., López-Martín, S., Ursa, A., Álvarez, S., Kolesnikova, T.V., Vázquez, J., Sánchez-Madrid, F., et al. (2012). EWI-2 Association with a-Actinin Regulates T Cell Immune Synapses and HIV Viral Infection. J. Immunol. 189, 689-700.

Grumet, M., and Edelman, G.M. (1988). Neuron-glia cell adhesion molecule interacts with neurons and astroglia via different binding mechanisms. J. Cell Biol. 106, 487-503.

Haenisch, C., Diekmann, H., Klinger, M., Gennarini, G., Kuwada, J.Y., and Stuermer, C.A.O. (2005). The neuronal growth and regeneration associated Cntn1 (F3/F11/Contactin) gene is duplicated in fish: expression during development and retinal axon regeneration. Mol. Cell. Neurosci. 28, 361-374. Hatten, M.E., and Heintz, N. (1995). Mechanisms of neural patterning and specification in the developing cerebellum. Annu. Rev. Neurosci. 18, 385-408. Hemler, M.E. (2005). Tetraspanin functions and associated microdomains. Nat. Rev. Mol. Cell Biol. 6, 801-811.

Hortsch, M., and Umemori, H. (2009). The Sticky Synapse: Cell Adhesion Molecules and Their Role in Synapse Formation and Maintenance (Springer Science \& Business Media).

Kamiguchi, H., and Lemmon, V. (2000). IgCAMs: bidirectional signals underlying neurite growth. Curr. Opin. Cell Biol. 12, 598-605. 
Katic, J., Loers, G., Kleene, R., Karl, N., Schmidt, C., Buck, F., Zmijewski, J.W., Jakovcevski, I., Preissner, K.T., and Schachner, M. (2014). Interaction of the cell adhesion molecule $\mathrm{CHL} 1$ with vitronectin, integrins, and the plasminogen activator inhibitor-2 promotes CHL1-induced neurite outgrowth and neuronal migration. J. Neurosci. Off. J. Soc. Neurosci. 34, 14606-14623.

Kolesnikova, T.V., Kazarov, A.R., Lemieux, M.E., Lafleur, M.A., Kesari, S., Kung, A.L., and Hemler, M.E. (2009). Glioblastoma Inhibition by Cell Surface Immunoglobulin Protein EWI-2, In Vitro and In Vivo,. Neoplasia N. Y. N 11, 77-86.

Kondo, H., Yamamoto, M., Yamakuni, T., and Takahashi, Y. (1988). An immunohistochemical study of the ontogeny of the horizontal cell in the rat retina using an antiserum against spot 35 protein, a novel Purkinje cellspecific protein, as a marker. Anat. Rec. 222, 103-109.

Kuhar, S.G., Feng, L., Vidan, S., Ross, M.E., Hatten, M.E., and Heintz, N. (1993). Changing patterns of gene expression define four stages of cerebellar granule neuron differentiation. Dev. Camb. Engl. 117, 97-104.

Lemmon, V., Farr, K.L., and Lagenaur, C. (1989). L1-mediated axon outgrowth occurs via a homophilic binding mechanism. Neuron 2, 1597-1603. Liljelund, P., Ghosh, P., and van den Pol, A.N. (1994). Expression of the neural axon adhesion molecule $\mathrm{L} 1$ in the developing and adult rat brain. J. Biol. Chem. 269, 32886-32895.

Lindner, J., Rathjen, F.G., and Schachner, M. (1983). L1 mono- and polyclonal antibodies modify cell migration in early postnatal mouse 
cerebellum. Nature 305, 427-430.

Maness, P.F., and Schachner, M. (2007). Neural recognition molecules of the immunoglobulin superfamily: signaling transducers of axon guidance and neuronal migration. Nat. Neurosci. 10, 19-26.

Matsuda, T., and Cepko, C.L. (2004). Electroporation and RNA interference in the rodent retina in vivo and in vitro. Proc. Natl. Acad. Sci. U. S. A. 101, 16-22. Ménager, M.M., and Littman, D.R. (2016). Actin Dynamics Regulates Dendritic Cell-Mediated Transfer of HIV-1 to T Cells. Cell 164, 695-709.

Miyazaki, T., Fukaya, M., Shimizu, H., and Watanabe, M. (2003). Subtype switching of vesicular glutamate transporters at parallel fibre-Purkinje cell synapses in developing mouse cerebellum. Eur. J. Neurosci. 17, 2563-2572.

Montpellier, C., Tews, B.A., Poitrimole, J., Rocha-Perugini, V., D’Arienzo, V., Potel, J., Zhang, X.A., Rubinstein, E., Dubuisson, J., and Cocquerel, L. (2011). Interacting regions of CD81 and two of its partners, EWI-2 and EWI-2wint, and their effect on hepatitis C virus infection. J. Biol. Chem. 286, 1395413965.

Nolte, C., Matyash, M., Pivneva, T., Schipke, C.G., Ohlemeyer, C., Hanisch, U.K., Kirchhoff, F., and Kettenmann, H. (2001). GFAP promoter-controlled EGFP-expressing transgenic mice: a tool to visualize astrocytes and astrogliosis in living brain tissue. Glia 33, 72-86.

Persohn, E., and Schachner, M. (1987). Immunoelectron microscopic localization of the neural cell adhesion molecules L1 and N-CAM during postnatal development of the mouse cerebellum. J. Cell Biol. 105, 569-576. 
Pickford, L.B., Mayer, D.N., Bolin, L.M., and Rouse, R.V. (1989). Transiently expressed, neural-specific molecule associated with premigratory granule cells in postnatal mouse cerebellum. J. Neurocytol. 18, 465-478.

Powell, S.K., Rivas, R.J., Rodriguez-Boulan, E., and Hatten, M.E. (1997). Development of polarity in cerebellar granule neurons. J. Neurobiol. 32, 223236.

Preibisch, S., Saalfeld, S., and Tomancak, P. (2009). Globally optimal stitching of tiled 3D microscopic image acquisitions. Bioinforma. Oxf. Engl. 25, $1463-1465$.

Ray, A., and Treloar, H.B. (2012). IgSF8: a developmentally and functionally regulated cell adhesion molecule in olfactory sensory neuron axons and synapses. Mol. Cell. Neurosci. 50, 238-249.

Rivas, A., Ruegg, C.L., Zeitung, J., Laus, R., Warnke, R., Benike, C., and Engleman, E.G. (1995). V7, a novel leukocyte surface protein that participates in T cell activation. I. Tissue distribution and functional studies. J. Immunol. Baltim. Md 1950 154, 4423-4433.

Ruegg, C.L., Rivas, A., Madani, N.D., Zeitung, J., Laus, R., and Engleman, E.G. (1995). V7, a novel leukocyte surface protein that participates in T cell activation. II. Molecular cloning and characterization of the V7 gene. J. Immunol. Baltim. Md 1950 154, 4434-4443.

Sakurai, T., Lustig, M., Babiarz, J., Furley, A.J., Tait, S., Brophy, P.J., Brown, S.A., Brown, L.Y., Mason, C.A., and Grumet, M. (2001). Overlapping functions of the cell adhesion molecules $\mathrm{Nr}-\mathrm{CAM}$ and $\mathrm{L} 1$ in cerebellar granule cell 
development. J. Cell Biol. 154, 1259-1273.

Sala-Valdés, M., Ursa, A., Charrin, S., Rubinstein, E., Hemler, M.E., SánchezMadrid, F., and Yáñez-Mó, M. (2006). EWI-2 and EWI-F link the tetraspanin web to the actin cytoskeleton through their direct association with ezrinradixin-moesin proteins. J. Biol. Chem. 281, 19665-19675.

Saupe, S., Roizès, G., Peter, M., Boyle, S., Gardiner, K., and De Sario, A. (1998). Molecular cloning of a human cDNA IGSF3 encoding an immunoglobulin-like membrane protein: expression and mapping to chromosome band 1p13. Genomics 52, 305-311.

Schachner, M. (1997). Neural recognition molecules and synaptic plasticity. Curr. Opin. Cell Biol. 9, 627-634.

Schaefer, A.W., Schoonderwoert, V.T.G., Ji, L., Mederios, N., Danuser, G., and Forscher, P. (2008). Cytoskeletal Dynamics Underlying Neurite Outgrowth. Dev. Cell 15, 146-162.

Schäfer, M.K.E., and Frotscher, M. (2012). Role of L1CAM for axon sprouting and branching. Cell Tissue Res. 349, 39-48.

Schmitt, A., Asan, E., Püschel, B., and Kugler, P. (1997). Cellular and regional distribution of the glutamate transporter GLAST in the CNS of rats: nonradioactive in situ hybridization and comparative immunocytochemistry. J. Neurosci. Off. J. Soc. Neurosci. 17, 1-10.

Shapiro, L., Love, J., and Colman, D.R. (2007). Adhesion molecules in the nervous system: structural insights into function and diversity. Annu. Rev. Neurosci. 30, 451-474. 
Soares, S., Traka, M., von Boxberg, Y., Bouquet, C., Karagogeos, D., and Nothias, F. (2005). Neuronal and glial expression of the adhesion molecule TAG-1 is regulated after peripheral nerve lesion or central neurodegeneration of adult nervous system. Eur. J. Neurosci. 21, 1169-1180.

Sotelo, C. (2004). Cellular and genetic regulation of the development of the cerebellar system. Prog. Neurobiol. 72, 295-339.

Stipp, C.S., Kolesnikova, T.V., and Hemler, M.E. (2001). EWI-2 is a major CD9 and CD81 partner and member of a novel lg protein subfamily. J. Biol. Chem. 276, 40545-40554.

Stipp, C.S., Kolesnikova, T.V., and Hemler, M.E. (2003). EWI-2 regulates alpha3beta1 integrin-dependent cell functions on laminin-5. J. Cell Biol. 163, $1167-1177$.

Stoeckli, E.T. (2004). Ig superfamily cell adhesion molecules in the brain. Handb. Exp. Pharmacol. 373-401.

Stoeckli, E.T. (2010). Neural circuit formation in the cerebellum is controlled by cell adhesion molecules of the Contactin family. Cell Adhes. Migr. 4, 523526.

Stottmann, R.W., and Rivas, R.J. (1998). Distribution of TAG-1 and synaptophysin in the developing cerebellar cortex: relationship to Purkinje cell dendritic development. J. Comp. Neurol. 395, 121-135.

Tabata, T., Sawada, S., Araki, K., Bono, Y., Furuya, S., and Kano, M. (2000). A reliable method for culture of dissociated mouse cerebellar cells enriched for Purkinje neurons. J. Neurosci. Methods 104, 45-53. 
Takahashi-Iwanaga, H., Kondo, H., Yamakuni, T., and Takahashi, Y. (1986). An immunohistochemical study on the ontogeny of cells immunoreactive for spot 35 protein, a novel Purkinje cell-specific protein, in the rat cerebellum. Brain Res. 394, 225-231.

Thelen, K., Kedar, V., Panicker, A.K., Schmid, R.-S., Midkiff, B.R., and Maness, P.F. (2002). The neural cell adhesion molecule L1 potentiates integrin-dependent cell migration to extracellular matrix proteins. J. Neurosci. Off. J. Soc. Neurosci. 22, 4918-4931.

Walsh, F.S., and Doherty, P. (1997). Neural cell adhesion molecules of the immunoglobulin superfamily: role in axon growth and guidance. Annu. Rev. Cell Dev. Biol. 13, 425-456.

Wang, H.-X., Sharma, C., Knoblich, K., Granter, S.R., and Hemler, M.E. (2015). EWI-2 negatively regulates TGF- $\beta$ signaling leading to altered melanoma growth and metastasis. Cell Res. 25, 370-385.

Wang, W., Karagogeos, D., and Kilpatrick, D.L. (2011). The Effects of Tag-1 on the Maturation of Mouse Cerebellar Granule Neurons. Cell. Mol. Neurobiol. 31, 351-356.

Washbourne, P., Dityatev, A., Scheiffele, P., Biederer, T., Weiner, J.A., Christopherson, K.S., and El-Husseini, A. (2004). Cell Adhesion Molecules in Synapse Formation. J. Neurosci. 24, 9244-9249.

Wiencken-Barger, A.E., Mavity-Hudson, J., Bartsch, U., Schachner, M., and Casagrande, V.A. (2004). The Role of L1 in Axon Pathfinding and Fasciculation. Cereb. Cortex 14, 121-131. 
Wilson, P.M., Fryer, R.H., Fang, Y., and Hatten, M.E. (2010). Astn2, a novel member of the astrotactin gene family, regulates the trafficking of ASTN1 during glial-guided neuronal migration. J. Neurosci. Off. J. Soc. Neurosci. 30, 8529-8540.

Xenaki, D., Martin, I.B., Yoshida, L., Ohyama, K., Gennarini, G., Grumet, M., Sakurai, T., and Furley, A.J.W. (2011). F3/contactin and TAG1 play antagonistic roles in the regulation of sonic hedgehog-induced cerebellar granule neuron progenitor proliferation. Development 138, 519-529.

Yamamoto, M., Boyer, A.M., Crandall, J.E., Edwards, M., and Tanaka, H. (1986). Distribution of stage-specific neurite-associated proteins in the developing murine nervous system recognized by a monoclonal antibody. J. Neurosci. Off. J. Soc. Neurosci. 6, 3576-3594.

Yamamoto, M., Hassinger, L., and Crandall, J.E. (1990). Ultrastructural localization of stage-specific neurite-associated proteins in the developing rat cerebral and cerebellar cortices. J. Neurocytol. 19, 619-627.

Yamasaki, T., Kawaji, K., Ono, K., Bito, H., Hirano, T., Osumi, N., and Kengaku, M. (2001). Pax6 regulates granule cell polarization during parallel fiber formation in the developing cerebellum. Dev. Camb. Engl. 128, 31333144.

Yoshihara, Y., Oka, S., Ikeda, J., and Mori, K. (1991). Immunoglobulin superfamily molecules in the nervous system. Neurosci. Res. 10, 83-105.

Zemni, R., Bienvenu, T., Vinet, M.C., Sefiani, A., Carrié, A., Billuart, P., McDonell, N., Couvert, P., Francis, F., Chafey, P., et al. (2000). A new gene 
involved in X-linked mental retardation identified by analysis of an $\mathrm{X} ; 2$ balanced translocation. Nat. Genet. 24, 167-170.

Zhang, X.A., Lane, W.S., Charrin, S., Rubinstein, E., and Liu, L. (2003). EWI2/PGRL associates with the metastasis suppressor KAI1/CD82 and inhibits the migration of prostate cancer cells. Cancer Res. 63, 2665-2674. 


\section{FIGURE LEGENDS}

Fig.1. IGSF3 is expressed in the developing mouse brain.

(A) mRNA expression of the four EWI family members assessed by quantitative RT-PCR at different stages of mouse cerebellar development.

Data are normalized to the housekeeping gene Gapdh. Mean \pm SEM of 3 independent experiments.

(B) Expression of the lgsf3 mRNA in various regions of the mouse brain detected by in situ hybridization at postnatal day 0 (P0), P7 and adult stage. Scale bar $=500 \mu \mathrm{m}$.

(C) Expression of the IGSF3 protein detected by anti-IGSF3 immunohistochemistry on sections from P0, P7 and adult mouse brain. Scale bar $=500 \mu \mathrm{m}$.

Fig. 2. IGSF3 is expressed in the developing granule cell and molecular layers of the cerebellum.

(A) Igsf3 mRNA expression detected by in situ hybridization in the mouse cerebellum at P0 and P7. Scale bar $=100 \mu \mathrm{m}$.

(B) IGSF3 protein localization detected by immunohistochemistry in the mouse cerebellum at P0 and P7. Scale bar=100 $\mu \mathrm{m}$.

(C) Co-immunolabeling on P7 cerebellar sections using the anti-IGSF3 antibody and an antibody against calbindin (CaBP) to label Purkinje cells specifically. Scale bar $=10 \mu \mathrm{m}$. 
External granular layer (EGL), molecular layer (ML), Purkinje cell layer (PCL), Internal granular layer (IGL).

Fig. 3. IGSF3 is expressed by granule cells and by some glial cells in the developing cerebellum.

(A) Co-immunolabeling for IGSF3 and PAX6, a marker of postmitotic granule cells, in P7 mouse brain sections. Scale bar $=50 \mu \mathrm{m}$.

(B) Co-immunolabeling for IGSF3 and PAX6, a marker of postmitotic granule cells, in mixed cerebellar cultures at days in vitro 0 (DIV0).

Scale bar $=20 \mu \mathrm{m}$.

(C) Immunolabeling for IGSF3 (green) in cerebellar sections from a transgenic mouse expressing eGFP in astrocytes and radial glial cells (GFAP-eGFP). Scale bar $=10 \mu \mathrm{m}$.

(D) High magnification of the region indicated in C (white rectangle). IGSF3 immunostaining overlaps partially with some glial fibers, particularly in the ML. Scale bar $=10 \mu \mathrm{m}$.

(E) Co-immunolabeling for IGSF3 and GLAST, a marker of glial cells, in mixed cerebellar cultures at DIV0. Hoechst counterstaining in blue. IGSF3 is expressed in some glial cells (arrows). Scale bar $=20 \mu \mathrm{m}$.

External granular layer (EGL), Molecular layer (ML), Purkinje cell layer (PCL), Internal granular layer (IGL).

Fig. 4. IGSF3 is concentrated in developing granule cell axonal terminals.

(A) Co-immunolabeling for IGSF3 and TAG-1, a marker for premigratory granule neurons, in P7 mouse brain sections. Scale bar $=50 \mu \mathrm{m}$. 
(B) High magnification of the region defined by the white rectangle in Figure 4A shows colocalization of IGSF3 with TAG-1. Scale bar $=10 \mu \mathrm{m}$.

(C) Co-immunolabeling for IGSF3 and L1-CAM, a marker for granule cell axonal terminals, in P7 mouse brain sections. Scale bar $=50 \mu \mathrm{m}$.

(D) High magnification of the region defined by the white rectangle in Figure 4C shows extensive colocalization of IGSF3 with L1-CAM. Scale bar $=10 \mu \mathrm{m}$. (E) Co-immunolabeling for IGSF3 and vGLUT-1, a marker for mature parallel Fiber/Purkinje cell synapses, in P7 mouse brain sections. Scale bar $=50 \mu \mathrm{m}$.

(F) High magnification of the region defined by the white rectangle in Figure 4E shows only partial colocalization of IGSF3 with vGLUT1. Scale bar $=10$ $\mu \mathrm{m}$.

External granular layer (EGL), Molecular layer (ML), Purkinje cell layer (PCL), Internal granular layer (IGL).

\section{Fig. 5. IGSF3 controls cerebellar granule cell morphogenesis.}

(A) Expression of Igsf3 and Igsf8 mRNAs in cerebellar granule cell cultures at different days in vitro (DIV) assessed by quantitative RT-PCR. Data are relative to the housekeeping gene Rp/13. Mean \pm SEM of 3 independent experiments.

(B) Left: Cell density in cerebellar granule cell cultures at different DIVs. siRNA treatment was started at DIV0. siCTR: Accell non-targeting control siRNA; silGSF3: Accell siRNA targeting mouse silGSF3. No significant effect was detected. Two-way ANOVA. 
Right: Percentage of proliferating cells expressing the proliferation marker Ki67 in cerebellar granule cell cultures at different DIVs. Mean \pm SEM, 3-6 independent experiments per condition. No significant effect was detected. Two-way ANOVA.

(C) Top: Images from representative cerebellar granule cells transfected with membrane GFP. siCTR, Accell non-targeting control siRNA; silGSF3, Accell siRNA targeting mouse silGSF3. Treatment started at DIV0, analysis at DIV4. Scale bar $=50 \mu \mathrm{m}$.

Bottom: Quantitative analysis of total dendritic length, number and mean length of dendrites as well as number of branches and total axonal length per granule cell. Mean \pm SEM of 3 independent experiments, $20-25$ cells, ${ }^{*} p<0.05$. Unpaired T-test.

(D) Top: Images from representative granule cells transfected with the empty pCAG vector + pCAG-mbGFP (CTR) or pCAG-IGSF3 + pCAG-mbGFP (IGSF3) at DIV1 and analyzed at DIV4. Scale bar $=50 \mu \mathrm{m}$.

Bottom: Quantitative analysis of total dendritic length, number and mean length of dendrites as well as number of branches and total axonal length per granule cell. Mean \pm SEM of 3 independent experiments, 20-25 cells, ${ }^{* *} p<0.001,{ }^{* *} p<0.01,{ }^{*} p<0.05$. Unpaired T-test.

Fig. 6. The tetraspanin TSPAN7 regulates axonal morphogenesis of cerebellar granule cells.

(A) Upper left: Expression of Tspan7 mRNA in mouse cerebellum at different developmental stages assessed by quantitative RT-PCR. Data are relative to the housekeeping gene Gapdh. MeanะSEM of 3 independent experiments. 
Upper right and bottom: Tspan7 mRNA brain expression at P7 analyzed by in situ hybridization on coronal and sagittal sections (Brain Gene Expression Map, http://www.stjudebgem.org/).

(B) Left: Images from representative granule cells transfected with the pIRESGFP vector (CTL) or pTSPAN7-IRES-GFP vector (TSPAN7) at DIV1 and analyzed at DIV4. Scale bar $=50 \mu \mathrm{m}$.

Right: Quantitative analysis of the total dendritic length, the number and the mean length of dendrites as well as the number of branches and total axonal length per granule cell. Mean \pm SEM of 4 independent experiments, 21 cells, unpaired $t$ test, ${ }^{*} p<0.05$.

Fig. 7. IGSF3 negatively regulates the size of TSPAN7 clusters in cerebellar granule cells.

A. IGSF3/TSPAN7 complex in the mouse brain detected by IGSF3 affinitypurification from P8 cerebella. 4\% Total input lysate (IN), 4\% flow through (FT), 50\% Immunoprecipitates (IP); control: beads coated with IgG (IP IgG), IGSF3 pull down: beads coated with IGSF3 antibody (IP IGSF3).

Samples were probed for the presence of IGSF3 (upper panel), L1-CAM (middle panel), TSPAN7 (bottom panel).

(B) Co-localization of IGSF3 and TSPAN7 shown by immunofluorescent labeling of transfected HEK293H cells. Scale bar $=10 \mu \mathrm{m}$.

(C) Co-localization of endogenous IGSF3 and TSPAN7 shown by immunofluorescent labeling of DIV4 cerebellar granule cells. Scale bar $=10$ $\mu \mathrm{m}$. 
(D) Top: Images from representative cerebellar granule cells immunostained for endogenous IGSF3 and TSPAN7 with or without IGSF3 knockdown. siCTR, Accell non-targeting control siRNA; silGSF3, Accell siRNA targeting mouse silGSF3. Treatment started at DIV0, analysis at DIV4. Scale bar $=10$ $\mu \mathrm{m}$.

Bottom: Quantitative analysis of the mean number per field and mean size of TSPAN7 clusters in cerebellar granule cell cultures. Mean \pm SEM of 4 independent experiments, 40 fields, unpaired T-test for number and Kolmogorov-Smirnov test for size, ${ }^{* * *} p<0.0001$. The frequency distributions are significantly different (Kolmogorov-Smirnov test, $p<0.0001)$.

\section{Supplementary Fig. 1. Specific immunodetection of mouse IGSF3} protein.

(A) Immunofluorescent labeling using a polyclonal antibody raised against human IGSF3 showed a specific labeling of HEK293 cells transiently transfected with a bidirectional vector co-expressing GFP and IGSF3, but not in those transfected with the vector coding for GFP alone. Scale bar $=50 \mu \mathrm{m}$. (B) Western blot analysis of protein lysates from HEK293 cells using the same antibody reveals two specific bands of molecular weight $\sim 200$ and $225 \mathrm{kDa}$ only in extracts from HEK293 cells transfected with GFP and IGSF3 (IGSF3 lane), but not in those from untransfected cells (NT lane). Beta-actin was used as a loading control. 
Supplementary Fig. 2. IGSF3 downregulation does not affect synaptogenesis.

(A) Quantitative RT-PCR analysis of Igsf3, Igsf8 and Bai3 mRNAs in extracts from cerebellar mixed cultures at different days in vitro (DIV) show a similar time course for Igsf3 as the one detected in vivo. Data are normalized to the housekeeping gene Gapdh. Mean \pm SEM of 3 independent experiments).

(B) Validation of specific IGSF3 knockdown by siRNAs in cerebellar mixed cultures using quantitative RT-PCR for Igsf3, Igsf8 and Bai3 mRNA.

Accell non-targeting control siRNA (siCTR), Accell siRNA targeting mouse silGSF3 (silGSF3). Data are relative to the housekeeping gene Gapdh and normalized to the control values. Mean \pm SEM of 3 independent experiments. ${ }^{* *} p<0.01$. Unpaired T-test.

(C) Validation of IGSF3 knockdown by siRNAs in cerebellar mixed cultures. Immunofluorescent staining for IGSF3 shows the level of IGSF3 protein, and Hoechst fluorescent nuclear staining cell density. Accell non-targeting control siRNA (siCTR), Accell siRNA targeting mouse silGSF3 (silGSF3). Scale bar $=$ $50 \mu \mathrm{m}$. Quantification shows a 48\% decrease in IGSF3 fluorescence intensity after knockdown, ${ }^{* * *} p<0.001$, unpaired T-test.

(D) Quantitative analysis of the number and size of excitatory synapses labeled using an antibody against VGLUT-1 in control cerebellar mixed cultures (siCTR) or after IGSF3 downregulation (silGSF3). Treatment starting at DIV0, analysis at DIV4. Mean \pm SEM of 3 independent experiments, total of 30 cells per condition, no statistical differences are observed. Unpaired T-test. 
Figure 1

A

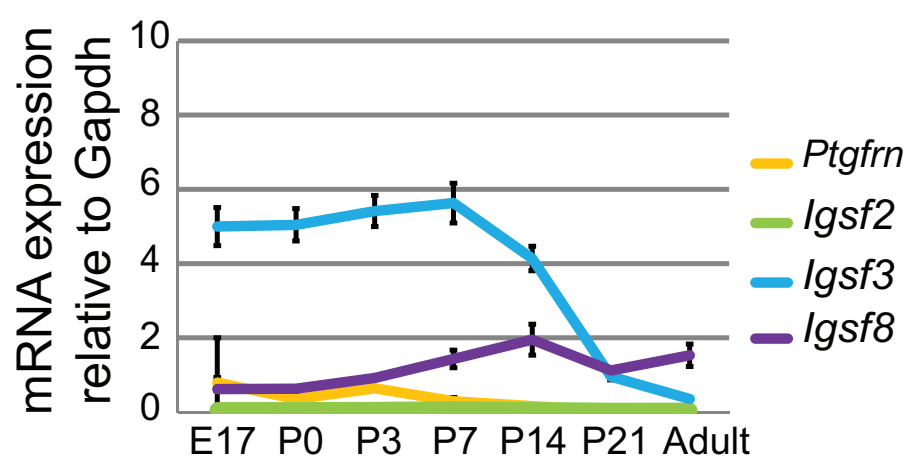

B Po

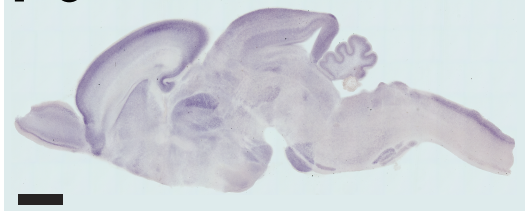

C PO

P7

Adult

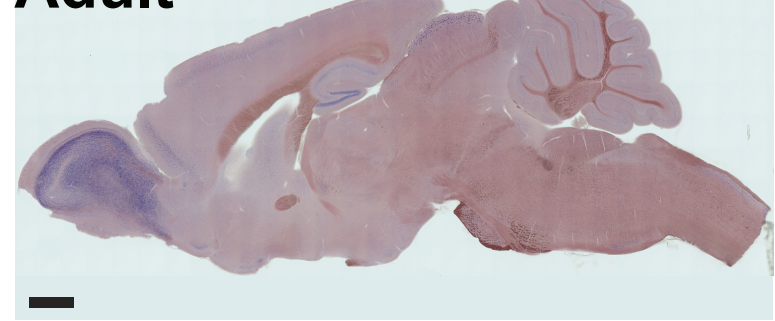

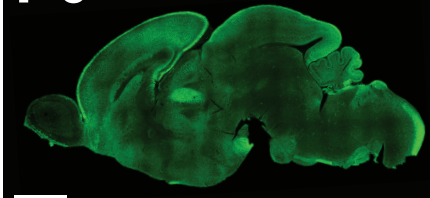

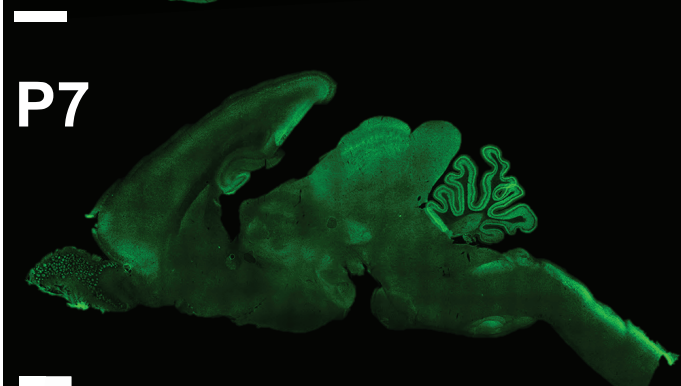

Adult

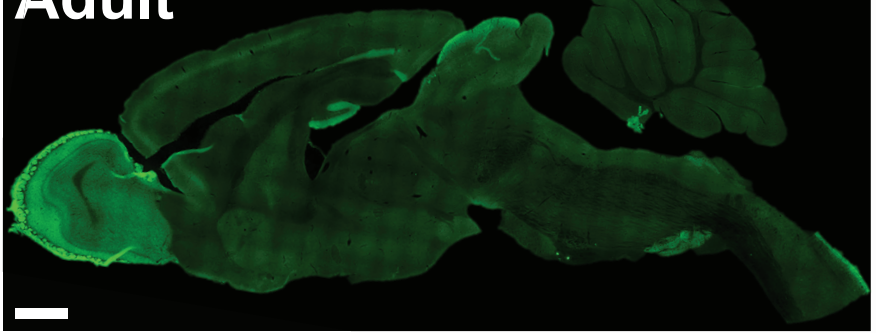


Figure 2

A Po

IGL
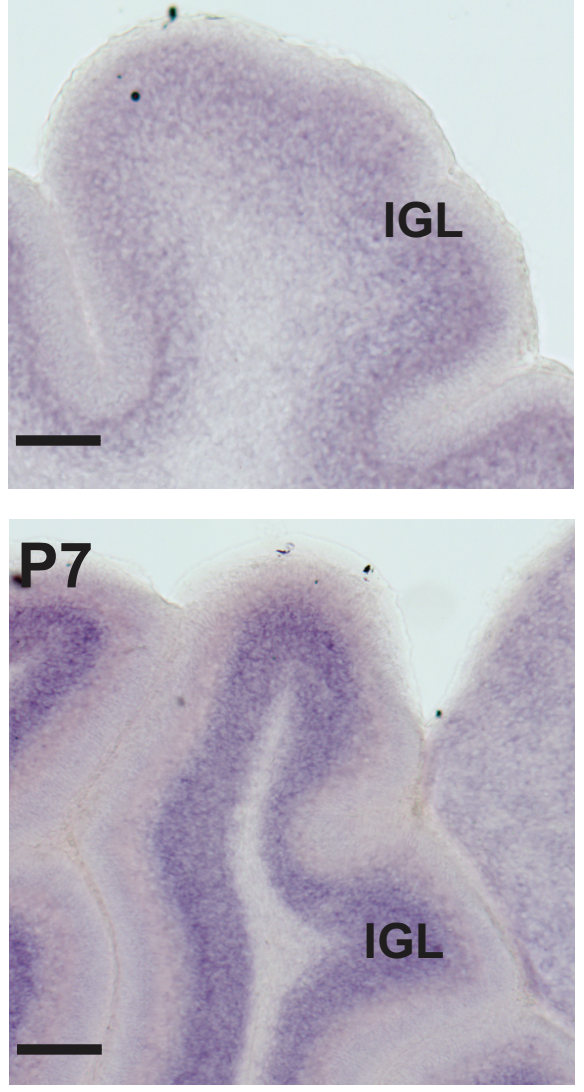

C

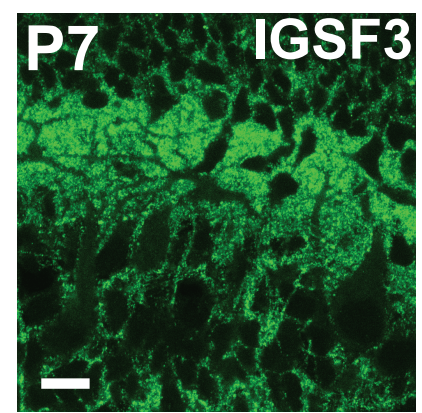

B PO

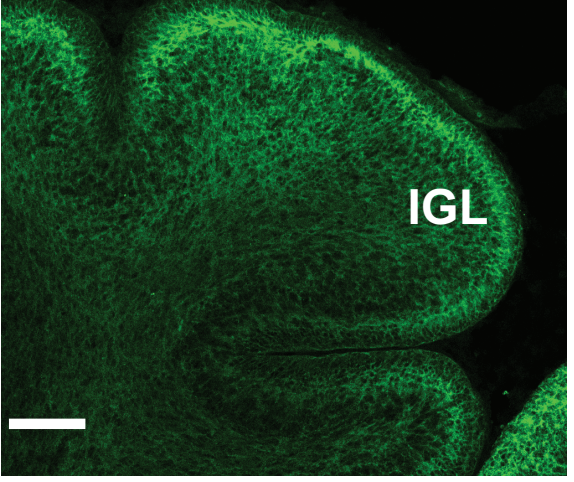

P7

IGL
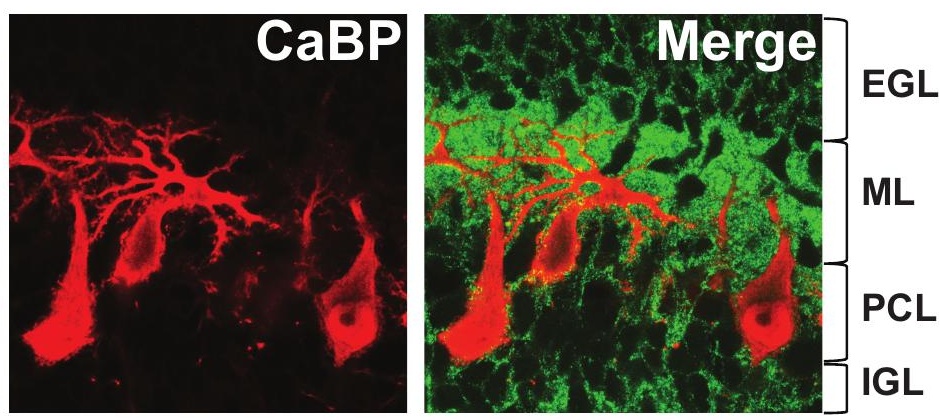